\title{
KSIAZŻKA KARDYNAŁA KAROLA WOJTYŁY MONOGRAFIĄ OSOBY JAKO PODMIOTU MORALNOŚCI
}

Napisana praca staje się wspólnym dobrem społeczności, jako adresata, któremu komunikuje się własne przemyślenia. Przeto w imię tego wspólnego dobra wolno nam podzielić się refleksjami, nie wykluczając nawet uwag krytycznych, które nie są przecież synonimem oceny negatywnej.

Wydaje mi się, że proponowane przez Autora rozwiązanie generalne da się sprowadzić do naczelnego twierdzenia: poprzez analizę czynu ludzkiego zaafirmować osobę jako podmiot tego czynu. Takie twierdzenie (oczywiście odczytane poprzez pracę) wydaje mi się w pełni uzasadnione zarówno ze stanowiska etyka jak i w mniejszym chyba stopniu, ze stanowiska metafizyka. Rzeczywiście bowiem podmiotowość osoby, czyli w naczelnym rozumieniu bytowość człowieka najdogodniej i najpełniej da się zaafirmować w czynie i poprzez czyn, gdyż tu właśnie osoba jawi się jaka byt sprawiajacy w sobie i dla siebie te nowe wypromieniowane ze siebie byty, których przedtem nie było. Podmiotowość osoby, a przez to podmiotowość ludzkiego bytu i jego bytowość jest niewątpliwie usprawiedliwiona i zagwarantowana w czynie ludzkim i jego ostatecznym rozumieniu.

Ale czy przez to samo uzyskaliśmy te orię człowieka, filozoficzną antropologię? Jeślibyśmy przez antropologię filozoficzną rozumieli taką teorię człowieka, która została skonstruowana przez filozoficzną analizę uniesprzeczniającą byt ludzki w kontekście jego istotnych i zasadniczych operacji ludzkich - to trzeba chyba dojść do wniosku negatywnego. Praca Kardynała Karola Wojtyły nie stanowi takiego typu antropologii, gdyż brak w niej analiz działalności człowieka w istotnych kontekstach ludzkiego życia. Jest jednak aspektowną antropologią, antropologią na 
użytek etyka, moralisty, a więc antropologią pozwalającą głębiej rozumieć człowieka, jako podmiot moralności.

Wszystko, co dalej powiem będzie teraz „wariacją” na temat tak właśnie sformułowany.

Cała tradycja literatury filozoficznej i teologicznej przedstawiała nam koncepcję osoby od strony zdeterminowanych potencjalności i zdeterminowanych źródeł działania człowieka. Mówiąc skrótowo, to poprzez analizę physis - natury starano się dojść nie tylko do ustalenia struktury bytu ludzkiego, ale także do odkrycia momentu osobowego człowieka - jakoby osoba jawiła się jako jakiś szczytowy moment natury, co zresztą chyba nie jest prawdą. Co nie znaczy, by osoba nie była momentem szczytowym bytu, ale znaczy jedynie, że osoba nie leży na linii rozwoju „,natury”, czyli zdeterminowanych układów działania. Jeślibyśmy zatem pojęli osobę jako źródło działania samo się determinujące, a nie „zdeterminowane", to opozycja między naturą a osobą stałaby się ostrzejsza. I właśnie praca Kardynała Wojtyły wydaje się pracą zasadniczo poświęconą osobie bytu ludzkiego; osobie jako bytowi w sensie naczelnym, bytowi który jest podmiotem w akcie podmiotowania, a więc wypromieniowania ze siebie bytowości niesamodzielnych, jakimi są ludzkie czyny. Ten moment jest niezwykle cenny i mało dotychczas w literaturze podkreślany. Ale wyakcentowanie strony podmiotowo-osobowej zostało związane ze zrezygnowaniem, czy też niedopracowaniem strony drugiej, więcej wiążącej się $\mathrm{z}$ analizą samej bytowej struktury a nawet teorią ludzkiej osoby. Podkreślenie bowiem momentu egzystencjalnego stawia mocniej stronę ,,ja” jako podmiotu, niedopracowaną zostaje natomiast strona treściowa. Brak więc analizy, np. tych charakterystycznych cech bytu osobowego, jakie zwykle wymienia się w klasycznym nurcie filozoficznym (poznanie, miłość, wolność, podmiotowość prawa, zupełność, godność). Brak jest też ukazania tych charakterystycznych struktur bytu ludzkiego, o których tyle pisano na tle klasycznych ujęć De anima. Te właśnie luki czy też świadome zrezygnowanie $\mathrm{z}$ analizy filozoficznej utrudniają akceptację monografii jako antropologii filozoficznej. Jest to raczej studium z dziedziny antropologii, zwłaszcza ewentualnej antropologii etycznej zbudowanej pod kątem ukazania podmiotowości osobowej człowieka, jako spełniacza czynu i za ten czyn odpowiedzialnego bytu osobowego. Przy czym moment „spełniania” czynu i poprzez ten czyn „spełniania się”, czy też „upełniania się” osoby jest szeroko rozbudowany do tego stopnia, że jest to monografia osoby jako podmiotu moralności. I chyba w literaturze światowej nie ma w tej mierze podobnej sobie monografii.

Powody tak zarysowanej i szeroko przedstawionej koncepcji widzialbym dwojakie. Pierwszy to profesja etyka i widzenia świata oraz ludzkiej 
osoby pod kątem etyki. W tym względzie sprawa jest i zrozumiała i zarazem doniosła. Ale czy tylko to? A może mamy tu ukryty postulat redukowalności filozofii świadomości do filozofii bytu? Tak właśnie kiedyś, przed kilku laty była postawiona sprawa na „Tygodniu filozoficznym" przez Autora analizowanej pracy. Jeśliby postulat ten miał być jakoś realizowany, to widziałbym znowu możliwość dwojaką:

a) Ograniczenie się do opisów stanów świadomości i tego, co się w świadomości dzieje - jako odbicia swoistego (intencjonalnego) rzeczywistości. W takim stanie rzeczy wszystkie treści poznawane i jawiące się w świadomości są aspektownym ujęciem rzeczywistości. Od strony tych treści zachodzi ich tożsamość z rzeczywistością, ale jest to tylko tożsamość jednostronna. Znaczy to, że ujęte w poznaniu treści są tożsame, $\mathrm{w}$ aspekcie ich ujęcia, z rzeczywistością, ale nie znaczy to, że sama rzeczywistość jest tożsama $z$ ujętymi treściami i jawiącymi się w mojej świadomości. Rzeczywistość jest nie tylko bogatsza i to nieskończenie, ale ona istnieje sama $\mathrm{w}$ sobie podmiotowo, podczas gdy ujęte $\mathrm{w}$ poznaniu treści (i jawiące się w świadomości) istnieją tylko moim istnieniem, istnieniem podmiotu poznającego. W tym stanie rzeczy danych świadomościowych nie można zredukować do rzeczywistości, gdyż są one tylko jej znakiem formalnym, przeźroczystym, ale aspektownie i selektywnie reprezentującym tę rzeczywistość.

b) Jeślibyśmy jednak - $z$ innego punktu widzenia, już nie poznawczego, ale ontycznego - w danych świadomościowych ujęli same akty, jako noszące treści poznawcze, jako przejawy i emanacje bytu podmiotowego osoby, wtedy — od strony realności aktu poznawczego, noszącego określoną treść - pozornie tylko analizowaliśmy akty świadomościowe, gdyż w gruncie rzeczy bylibyśmy na terenie ontologii, gdyż akty poznawcze jako akty podmiotu realnego, są także bytem realnym (akcydentalnym). Dla metafizyka jest ostatecznie sprawą obojętną czy poddaje się analizie jakieś byty materialne czy duchowe (akty poznania). I jedne i drugie są realne.

Ale właśnie przy analizie aktów duchowych, wypromieniowanych przez osobę poznającą spotykamy się z jedynie możliwym, danym nam do analizy „przejawem” samego podmiotu, świadczącym o podmiocie i wskazującym na strukturę podmiotu sprawiającego akt. I w analizie aktu tego można wyróżnić jego dwie strony: a) stronę ,od podmiotu”, o ile akt ten jest właśnie emanatem podmiotu; b) stronę drugą ,do przedmiotu", o ile aktem tym docieramy do określonego przedmiotu. W realnym akcie - podobnie jak w realnym kiju posiadającym dwa końce obie strony występują zawsze nierozdzielnie. Można jednak w analizie zatrzymać się lub poświęcić więcej uwagi na stronę pierwszą, na akt o ile ujmujemy go od strony podmiotowej, o ile on wyłania się z pod- 
miotu. Można jednak ten sam akt analizować od strony przedmiotowej, o ile on dociera do przedmiotu i przedmiot ten swoiście ,ujmuje”.

Oczywiście w akcie poznania, czy szerzej: w ludzkim życiu świadomościowym ujmowanych przedmiotów jest niezwykłe bogactwo. I dlatego nie chodziłoby o przedmiotowość jako przedmiotowość aktu poznawczego czy świadomościowego, ale o przedmiotowość podmiotową tego aktu. Chodzi o to w jaki s pos ób dokonuje się przez akt poznawczy, czy też akt duchowy ujęcie przedmiotu. Sposób ujmowania przedmiotu świadczy o samym podmiocie i wskazuje na jego charakterystyczne bytowe cechy. Analiza różnych aktów duchowych, świadomych — głównie zaś poznawczych, (ale nie tylko!) - może się stać narzędziem zbudowania antropologicznej teorii filozoficznej.

W omawianej tutaj pracy wydaje mi się brak analizy aktów duchowych człowieka od strony podmiotowej przedmiotowości, chociaz nieustannie spotykamy się z subtelnymi analizami strony pierwszej aktu, mianowicie aktu o ile wyłania się z podmiotu osobowego. Stało się tak dlatego, że analizy wychodzą spod pióra etyka, którego interesuje związek czynu z osobą. Ale przecież nie można zapominać, że sposób ujęcia przedmiotu, że sposób konstrukcji przedmiotu świadczy również o osobie i świadczy o niej ,obiektywnie”, ze względu na przedmiotowość tego czynu. Wydaje mi się, że w dużej mierze nie został wykorzystany w tej mierze myślowy dorobek Tomasza nie tylko z dziedziny antropologii, ale właśnie moralności, zwłaszcza zaś jego I-II Sumy Teologii, gdzie przecież spotykamy się ciągle $z$ analizą ludzkiego czynu ze względu na charakterystyczne dziedziny przedmiotu tego czynu; gdzie dokonane są analizy nie tylko różnych grup aktów podmiotu osobowego, ale - co jest niezwykle doniosłe - różnych wzajemnie się warunkujących i syntetyzujących w wielkiej funkcji czynności poznania, chcenia, wyboru; zarówno nieusprawnionego jak i usprawionego w kontekście prawa, namiętności poczucia debitum. Materiał już dawno przemyślany i przekazany w języku — może dzisiaj różnymi od naszego — jest jednak dorobkiem, który w dziedzinie antropologii, zwłaszcza etycznej, należy uwzględnić, gdyż ukazał on bardzo wiele cech człowieka, jako podmiotu moralnego czynu. A przemyślenie starego materiału w kontekście dzisiejszych prądów filozoficznych pozwoliłoby wydobyć wiele nowych wirtualności, zawartych w tekstach Tomasza. I nie chodzi tu o samego Tomasza, ale o prawdę, którą można by pełniej i jaśniej wyrazić uwzględniając analizy I-II jego Sumy.

Poznanie, które analizuje etyk czy moralista jest zasadniczo jednym tylko z typów ludzkiego poznania - poznaniem fronetycznym, a więc przyporządkowane działaniu i z nim związane. Tu wystarczy sobie przypomnieć dzieje teorii fronetycznego poznania od tragików greckich, He- 
raklita, Arystotelesa, Tomasza z Akwinu. A przecież człowiek posługuje się zasadniczo poznaniem typu informacyjnego i to $\mathrm{w}$ bardzo różnych jego postaciach i uwarunkowaniach. Przy konstruowaniu teorii człowieka nie można nie uwzględnić tego typu poznania i jego zasadniczych, węzłowych form świadczących o ludzkim podmiocie. W tym wszystkim nie bagatelną jest również sprawa ludzkiego ciała i jego roli w kształtowaniu się duchowego profilu człowieka. Wprawdzie o ciele w omawianej pracy mamy często uwagi, to jednak jego rola domaga się specjalnego dociekania i opracowania, gdyż ono właśnie jest tym czynnikiem, który warunkuje nie tylko uświadomienie siebie samemu sobie, ale także i rozwój wewnętrzny człowieka, zwłaszcza zaś jego rozwój moralny. Uwzględnienie w toku analizy roli ciała dokonuje się na tle konkretnych czynności manifestujących specyfikę ludzkiego bytu.

Słowem w zarysowanej koncepcji antropologii filozoficznej rozumienie człowieka oscyluje pomiędzy wyakcentowaniem roli osoby jako samoistniejącego ,ja" (czyli bytu-podmiotu w akcie podmiotowania) natury rozumnej. Natura i jej rola, jej struktura i sposoby działania domagają się również uwzględnienia i przeanalizowania. Praca akcentując moment egzystencjalny, moment osoby ludzkiej od strony faktyczności osoby (człowiek jako podmiot spełniający czyn!) wydaje mi się za mało uwzględniać zarówno teorię osoby (teorię manifestującą się w zanalizowaniu charakterystycznych momentów życia osobowego, jego specyficznych cech) oraz za mało też wyakcentowywać rolę, ,natury” człowieka. A przecież rozumienie człowieka przebiega na liniach spięcia się właśnie natury, czyli zdeterminowanych (od zewnątrz także!) źródeł działania i osoby, jako bytu wolnego samodeterminującego się do wyłonienia czynu. Skoro jednak w dotychczasowej literaturze momenty natury i struktury bywały zasadniczo analizowane i są znane czytelnikowi obeznanemu z filozofią, natomiast momenty życia osobowego, jako specyficznie osobowego - zwłaszcza od strony faktyczności osoby ludzkiej nie były znane - przeto zwrócenie uwagi na te właśnie momenty przez Kardynała Wojtyłę wydaje się niezmiernie cenne, twórcze i wzbogacające naszą wizję człowieka w ogóle, a zwłaszcza umożliwia głębsze rozumienie człowieka jako bytu tworzącego i przeżywającego porządek moralności. Jednak antropologia filozoficzna czeka na swoje opracowanie i mam nadzieję - praca moja, mająca się ukazać, będzie w pewnej mierze uzupełnieniem omawianej tu monografii. 